\title{
Induction of Tolerance through Mixed Chimerism
}

\author{
David H. Sachs ${ }^{1}$, Tatsuo Kawai ${ }^{2}$, and Megan Sykes ${ }^{3}$ \\ ${ }^{1}$ Transplantation Biology Research Center, Massachusetts General Hospital, Harvard Medical School, \\ Boston, Massachusetts 02129 \\ ${ }^{2}$ Transplant Center, Massachusetts General Hospital, Harvard Medical School, Boston, Massachusetts 02115 \\ ${ }^{3}$ Columbia Center for Translational Immunology, Columbia University Medical Center, New York, \\ New York 10032 \\ Correspondence: sachs@helix.mgh.harvard.edu
}

\begin{abstract}
"Mixed chimerism" refers to a state in which the lymphohematopoietic system of the recipient of allogeneic hematopoietic stem cells comprises a mixture of host and donor cells. This state is usually attained through either bone marrow or mobilized peripheral blood stem cell transplantation. Although numerous treatment regimens have led to transplantation tolerance in mice, the induction of mixed chimerism is currently the only treatment modality that has been successfully extended to large animals and to the clinic. Here we describe and compare the use of mixed chimerism to establish transplantation tolerance in mice, pigs, monkeys, and in the clinic. We also attempt to correlate the mechanisms involved in achieving tolerance with the nature of the tolerance that has resulted in each case.
\end{abstract}

It has been known for many years that the hematopoietic chimerism that occurs after bone marrow transplantation carries with it transplantation tolerance for any other tissue or organ from the same donor. This phenomenon has been observed not only in numerous animal models, but also in humans. Thus, patients treated during childhood for leukemia by bone marrow transplantation from an HLAidentical sibling, who have subsequently developed renal failure and received kidney transplants from the same donors, have not required immunosuppression (Sayegh et al. 1991; Helg et al. 1994; Jacobsen et al. 1994). These cases, however, represent a very specialized situation, in which the transplants were HLA identical and in which complete replacement of the bone marrow was desirable in order to ensure ablation of the hematopoietic malignancy.

In the more common situation for organ transplantation, donors and recipients are not HLA identical, and it would also not be desirable to completely replace all bone marrow elements, because immunocompetence depends on interactions between $\mathrm{T}$ cells educated in the thymus and bone-marrow-derived antigenpresenting cells in the periphery (Zinkernagel et al. 1980). Fortunately, for the induction of transplantation tolerance through hematopoietic chimerism, complete ablation and re-

Editors: Laurence A. Turka and Kathryn J. Wood

Additional Perspectives on Transplantation available at www.perspectivesinmedicine.org

Copyright (C) 2014 Cold Spring Harbor Laboratory Press; all rights reserved; doi: 10.1101/cshperspect.a015529

Cite this article as Cold Spring Harb Perspect Med 2014;4:a015529 
D.H. Sachs et al.

constitution are not required. The survival of even a small percentage of donor bone-marrow-derived elements, even transiently, has been found to be sufficient to allow tolerance of a simultaneously transplanted organ to be achieved (Fuchimoto et al. 1999). This phenomenon, in which both host and donor bonemarrow-derived elements coexist in the recipient has been termed "mixed chimerism" (Sykes and Sachs 1988). Unlike many other treatment regimens that have been successful in the induction of tolerance in rodents but not in large animals (Sachs 2003; Cosimi and Sachs 2004), induction of tolerance through mixed chimerism has been successful in mice, in large animals, and, most recently, in the clinic.

Nevertheless, this transition from mice to the clinic has required numerous changes in treatment protocols, and the tolerance obtained has likely been achieved through more than one mechanism. In this review, we describe and compare the establishment of transplantation tolerance in mice, pigs, monkeys, and in the clinic, with an attempt to correlate the mechanisms involved in achieving tolerance with the nature of the tolerance that has resulted in each case.

\section{STUDIES IN MOUSE MODELS}

Proof of principle that mixed chimerism was associated with donor-specific skin graft tolerance was obtained in adult mice receiving lethal total body irradiation (TBI) and reconstitution with a mixture of T-cell-depleted host plus donor bone marrow. Mixed lymphohematopoietic chimerism was observed, in which all lymphoid and hematopoietic cells are derived from a mixture of donor- and host-derived hematopoietic stem cells (HSCs). The tolerant state was systemic, as evidenced by in vitro measures of alloreactivity. Graft-versus-host disease (GVHD) was avoided by T-cell depletion of the donor marrow component, and depletion of the recipient marrow component was required to prevent rejection of the donor marrow (Ildstad and Sachs 1984; Ildstad et al. 1985, 1986). Using a different approach, mixed chimerism and tolerance without GVHD were also shown in mice receiving fractionated high-dose total lymphoid irradiation (TLI) conditioning with shielding of marrow-containing bones before allogeneic BMT (Slavin et al. 1977).

GVHD is the major complication of clinical hematopoietic cell transplantation (HCT) that has precluded the routine use of extensively HLA-mismatched donors even in patients with malignancies. Although a low level of GVHD is associated with improved outcomes owing to reduced leukemic relapse rates in patients receiving BMT for this more standard indication (Weiden et al. 1981), its severity is unacceptable when HLA barriers are transgressed, mandating a search for closely HLAmatched donors in this patient group. Even a low level of GVHD would be an unacceptable complication if HCT were to be used expressly for the purpose of organ allograft tolerance induction. Although GVHD can be avoided by T-cell-depleting the donor product, rejection of HLA mismatched hematopoietic cells then becomes common, and very heavy host conditioning is needed to prevent rejection (Martin et al. 1985, 1988; Kernan et al. 1987; Bordignon et al. 1989; Fleischhauer et al. 1990; Aversa et al. 1998). Because organ transplantation is routinely performed across extensive HLA barriers, avoiding GVHD while crossing HLA barriers is a major challenge for the induction of mixed chimerism and tolerance.

The challenge is further augmented by the requirement that relatively nontoxic, low-intensity conditioning is mandated in using HCT for this purpose. The high-dose chemo-/radiotherapy regimens used for patients with malignant disease would not be appropriate in patients receiving HCT for tolerance induction. To reduce the toxicity of recipient conditioning regimens, it is necessary to more specifically target the host immune elements that resist allogeneic marrow engraftment. Recipient $\mathrm{T}$ cells are largely responsible for rejection of MHC mismatched marrow in animals and humans (Sharabi et al. 1992; Vallera et al. 1994; Hayashi et al. 1996), and a low-toxicity host conditioning regimen must either eliminate mature host $\mathrm{T}$ cells or permit preexisting $\mathrm{T}$ cells to be rendered tolerant. This requirement applies to both 
peripheral and intrathymic alloreactive T cells. When peripheral $\mathrm{T}$ cells are globally depleted with mAbs and thymocytes are globally depleted with local irradiation before allogeneic BMT with low-dose (3 Gy) TBI (Sharabi and Sachs 1989), donor- and host-reactive T cells arising de novo in the thymus are specifically deleted (Tomita et al. 1994, 1996a,b; Khan et al. 1996; Manilay et al. 1998). Coexistence of donor and recipient HSCs in the marrow generates lifelong thymic APCs of each type to ensure central, deletional T-cell tolerance (Tomita et al. 1994, 1996a,b; Khan et al. 1996; Manilay et al. 1998). This model built on an earlier regimen requiring 6 Gy of TBI combined with in vivo depletion of host $\mathrm{T}$ cells to achieve MHC-mismatched allogeneic marrow engraftment and donor-specific tolerance (Cobbold et al. 1990). Because T-cell-depleting mAbs almost completely eliminate peripheral but not intrathymic T cells (Sharabi and Sachs 1989), the addition of thymic irradiation, which eliminates mature alloreactive thymocytes (Nikolic et al. 2001), was needed to reduce the TBI requirement to only $3 \mathrm{~Gy}$. Intrathymic clonal deletion maintains long-term donor-specific tolerance in association with the presence of donor class II ${ }^{\text {high }}$ cells (Tomita et al. 1994). Several lines of evidence (Khan et al. 1996) proved that intrathymic chimerism is necessary and sufficient for the maintenance of tolerance. These studies showed that peripheral chimerism and suppressive mechanisms did not play a meaningful role in the maintenance of tolerance in these mixed chimeras that were created in the environment of a completely T-cell-depleted "clean slate."

We subsequently developed conditioning regimens that are less T-cell-depleting than that described above and that involve more complex mechanisms in order to achieve initial mixed chimerism. Both thymic irradiation and T-cell-depleting mAbs can be avoided if an initial course of costimulatory blockade is used (Wekerle et al. 1998), and TBI can be eliminated if a high enough marrow dose is administered (Wekerle et al. 2000). If applied clinically, these approaches would obviate concerns about delayed T-cell recovery in older individuals with limited thymic function (Haynes et al. 2000).
Once mixed chimerism is achieved with costimulatory blockade-based regimens, long-term tolerance is maintained by intrathymic deletion (Wekerle et al. 1998, 2000; Ito et al. 2001). Preexisting peripheral $\mathrm{T}$ cells that recognize the donor in recipients of anti-CD154 plus allogeneic BMT are specifically deleted, but the remainder of the T-cell repertoire is spared (Kurtz et al. 2004; Fehr et al. 2005). Mechanisms of tolerance of peripheral CD4 and CD8 cells differ in this context, although both culminate in deletion only of donor-reactive cells. For CD8 cells, initial tolerance requires CD4 cells that do not appear to be classical Tregs. Once peripheral deletion of donor-specific CD8 cells is complete (at $\sim 2 \mathrm{wk}$ ), CD4 cells are no longer needed for maintenance of CD8 tolerance (Fehr et al. 2005). Tolerance of CD4 cells, in contrast, does not involve any regulatory mechanisms (Kurtz et al. 2004). The expressions of MHC class II on recipient APCs, as well as recipient dendritic cells and B cells, all are also required to tolerize preexisting CD8 cells, but not CD4 cells, in this model (Fehr et al. 2008; Mollov et al. 2010). Moreover, PD-1/PD-L1 interactions are required to tolerize CD8 cells but not CD4 cells (Haspot et al. 2008), and the CD8 cells themselves must express PD-1 in order to be tolerized (Lucas et al. 2011). NFAT-1, also in a CD8-cellintrinsic manner, is required for CD8 tolerance and plays no role in tolerizing the CD4 compartment (Fehr et al. 2010). TGF- $\beta$ and LAG-3 also play a critical role in tolerizing preexisting CD8 but not CD4 cells in mice receiving BMT with anti-CD40L (Lucas et al. 2011). Tolerance of both subsets is independent of IFN- $\gamma$ and IL10 (Takeuchi et al. 2004; Fehr et al. 2005; Mollov et al. 2010). Deletion of peripheral donor-reactive CD4 and CD8 cells is preceded by specific unresponsiveness to the donor (Kurtz et al. 2001, 2004; Haspot et al. 2008).

Long-term tolerance involves central deletion of donor-reactive thymocytes. Regulatory cells do not play a significant role in maintaining long-term tolerance in this model of BMT with anti-CD40L (Ito et al. 2001; Kurtz et al. 2004; Takeuchi et al. 2004; Fehr et al. 2005). As a general rule, deletional tolerance seems to preclude the expansion and requirement for spe- 
D.H. Sachs et al.

cific regulatory cells in maintenance of tolerance. In contrast, some models using CTLA4Ig and anti-CD154 as conditioning for allogeneic BMT are associated with less complete deletion of preexisting donor-reactive $\mathrm{T}$ cells and do appear to rely on long-term regulatory mechanisms (Bemelman et al. 1998; Bigenzahn et al. 2005; Domenig et al. 2005).

Translation into patients of an approach that involved initial mixed chimerism induction in the treatment of hematologic malignancies in mouse models played an important role in the development of clinical mixed chimerism/ tolerance protocols. We have attempted to avoid GVHD to permit HLA-mismatched HCT for the treatment of hematologic malignancies in a series of clinical protocols by using nonmyeloablative conditioning with recipient and donor graft T-cell depletion to achieve initial mixed chimerism. Because conditioning-induced tissue inflammation is a critical checkpoint in the development of GVHD (Chakraverty et al. 2006a), MHC-directed GVH alloreactivity can be confined to the lymphohematopoietic system when nontolerant donor $\mathrm{T}$ cells are given to mixed chimeras after host recovery from the initial conditioning regimen has occurred (Sykes et al. 1988; Mapara et al. 2002, 2003; Chakraverty et al. 2006a,b). GVH reactions of nontolerant $\mathrm{T}$ cells in donor leukocyte infusions (DLI) are not opposed by a hostversus-graft response in tolerant mixed chimeras. The DLI convert mixed hematopoietic chimerism to full donor chimerism and mediate strong graft-versus-leukemia/lymphoma (GVL) effects (Sykes et al. 1988; Mapara et al. 2002) without inducing GVHD (Sykes et al. 1988; Pelot et al. 1999). Recipient professional APCs expressing both class I (Mapara et al. 2002) and class II (Chakraverty et al. 2006b) MHC are required to induce this antihost reactivity and maximal GVL. These DLI-derived GVH-reactive $T$ cells do not migrate to the epithelial GVHD target tissues (skin, intestines, and liver) in the absence of inflammatory signals in those tissues (Chakraverty et al. 2006a; Li et al. 2012). Clinical trials based on this approach to separating GVHD and GVL provided proof-ofprinciple that GVH responses can be confined to the lymphohematopoietic system following delayed DLI and thereby fail to induce GVHD in patients who received nonmyeloablative HCT with an initially T-cell-depleted product, even across extensive HLA barriers (Spitzer et al. 2003).

Translational studies aiming to apply this approach to separating GVHD and GVL in humans led to a clinical regimen with sufficient safety and antitumor efficacy to be used for renal allograft tolerance induction in multiple myeloma patients with HLA-identical donors (Fudaba et al. 2006). Attempts to apply this approach to separating GVHD and GVL in the HLA-mismatched related donor setting led to the development of a nonmyeloablative regimen that achieved transient chimerism without any GVHD in patients with hematologic malignancies (Spitzer et al. 2003). The freedom from GVHD in these mismatched recipients ultimately permitted the trials of allograft tolerance induction in patients without malignant disease that are described below.

\section{STUDIES IN SWINE}

Studies of mixed chimerism in swine have been performed in a herd of miniature swine that have been bred selectively for the past 40 years as a large-animal model for studies of transplantation (Sachs 1992; Hanekamp et al. 2012). These animals are similar to humans with regard to size and many physiological parameters (Sachs 1992, 1994). Because of their breeding characteristics, it has been possible to develop lines of swine homozygous for the MHC (called SLA in swine), as well as several recombinant lines separating the genes encoding class I and class II antigens (Pennington et al. 1981; Lunney and Sachs 1995). Figure 1 shows the three inbred haplotypes and several of the recombinant haplotypes currently available. These animals therefore represent a unique resource in which transplants across reproducible, defined genetic combinations can be performed in a large animal model

Early studies of bone marrow transplantation in miniature swine involved lethal irradiation as a preparative regimen, with full donor 


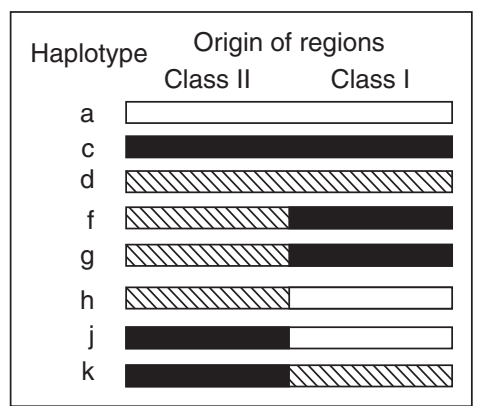

Figure 1. Origin of haplotypes of inbred miniature swine.

hematopoietic reconstitution as the result (Pennington et al. 1988; Popitz-Bergez et al. 1988; Sakamoto et al. 1988). Use of $F_{1}$ into parental and parental into $F_{1}$ combinations permitted the study of graft-versus-host (GVH) and host-versus-graft (HVG) reactions in this species, as well as an appreciation of the role of $\mathrm{T}$ cells in each (Sakamoto et al. 1987). Initial attempts to induce mixed chimerism across full two-haplotype SLA barriers used a lethal preparative regimen of $(650+650)$ cGy TBI on two successive days followed by infusion of $7.5 \times 108$ bone marrow cells $/ \mathrm{kg}+1.0 \times 10^{8}$ T-cell-depleted autologous bone marrow (BM) cells. Although there were a few long-term survivors (one animal survived $154 \mathrm{~d}$ ), most of the animals died earlier, either from the aplasia resulting from bone marrow rejection or from GVHD (Smith et al. 1993).

Better rates of engraftment and survival were obtained using a clinically relevant genetic combination of one-haplotype mismatched $\mathrm{F}_{1}$ into $\mathrm{F}_{1}$ (i.e., $\mathrm{AC}$ into $\mathrm{AD}$, simulating the clinical situation of haploidentical related) and a preparative regimen of either $(650+650)$ cGy TBI on two successive days or $(500+650)$ cGy TBI, and $50 \mathrm{mg} / \mathrm{kg}$ cyclophosphamide. Once some of these animals had attained prolong survival and immunocompetence, renal transplants from donors SLA-matched to the bone marrow donors were performed, and all animals were found to be tolerant of the kidneys (Sundt et al. 1988; Guzzetta et al. 1991).

T-cell depletion in these early experiments was achieved by treating the donor inoculum in vitro with available anti-CD4 and anti-CD8 monoclonal antibodies (Lunney and Pescovitz 1987; Pescovitz et al. 1990) and lethally ablating the recipients. Achievement of mixed chimerism with a nonmyeloablative preparative regimen awaited the development of a T-celldepleting reagent effective in vivo, because most of the anti-pig T-cell monoclonal antibodies available were capable of depleting in vitro in the presence of rabbit complement, but were poorly depleting in vivo. For this purpose, a swine CD3 immunotoxin, pCD3-CRM9, was developed by conjugating an available anti-pig CD3 monoclonal (Pescovitz et al. 1998; Huang et al. 1999a) with a mutant diphtheria toxin, developed by Neville et al. (1996). This reagent was found to be very effective for depleting mature $\mathrm{T}$ cells from the peripheral blood, lymph nodes, and thymus of miniature swine (Huang et al. 1999b). In addition, another source of hematopoietic stem cells was obtained through cytokine mobilization and apheresis, allowing collection of enormous numbers of peripheral blood stem cells (PBSC), which were capable of reconstituting ablated miniature swine just as effectively as bone marrow (Nash et al. 1999).

Huang et al. first reported the induction of stable mixed chimerism and donor-specific tolerance following either BM or PBSCs, using this CD3 immunotoxin for T-cell depletion in an SLA-matched combination (Huang et al. 1999b, 2000). Marrow was harvested from the long bones and/or vertebra following exsanguination of the donors, and $2 \times 10^{8}$ cells $/ \mathrm{kg}$ administered by intravenous injection (i.v.) PBSC were collected following daily mobilization with recombinant porcine stem cell factor ( $\mathrm{pSCF}$ ) and IL-3 (pIL-3), with or without recombinant human G-CSF (rhuG-CSF; Amgen), and $20 \times$ $10^{8}$ cells $/ \mathrm{kg}$ were administered. Irradiation consisted of two sequential daily doses of $150 \mathrm{cGy}$ midline TBI and 700 cGy thymic irradiation on $\mathrm{d}-2$. T-cell depletion was achieved by administering pCD3-CRM9 i.v. on $\mathrm{d}-2$, and immunosuppression consisted of oral cyclosporine from $\mathrm{d}-1$ to $\mathrm{d} 30$. Excellent T-cell depletion was achieved by this regimen, with $\mathrm{T}$ cell counts falling to $<0.2 \%$ of their pretransplant values, $\sim 30$-fold to 150 -fold greater de- 
D.H. Sachs et al.

pletion than the same preparative regimen without immunotoxin. Five of the six animals treated in this study developed stable mixed-lineage hematopoietic chimerism as well as thymic chimerism, and four of these animals that were subsequently tested with skin grafts showed markedly prolonged survival of donor versus third-party skin (Huang et al. 2000).

In subsequent studies, Fuchimoto et al. (2000) showed that a similar preparative regimen could also achieve stable mixed chimerism across a one-haplotype full SLA mismatch, and that by using a much larger dose of PBSC $(100 \times 108$ cells $/ \mathrm{kg})$, the requirement for TBI could be avoided. The resulting animals showed evidence for specific unresponsiveness to donor by MLR and CML reactions in vitro and by specific prolongation of donor skin graft survival in vivo. In addition, four of these animals subsequently received kidney allografts SLAmatched to the donors without immunosuppression. Three of these animals accepted these renal allografts long term. The fourth animal rejected its allograft but remained unresponsive in vitro to the donor SLA. A second donormatched kidney was therefore placed and survived for $>100 \mathrm{~d}$, suggesting that rejection of the first SLA-matched kidney might have been due to minor antigen disparities. All of these animals maintained peripheral mixed chimerism long term and showed chimerism of dendritic cells in the thymus by immunohistochemistry.

Because of an increased incidence of hostderived PTLD using this protocol, it was subsequently decided to add a low dose (100 cGy) of TBI back into the preparative regimen (Cina et al. 2006). It was also shown that, unlike the mouse (Sharabi and Sachs 1989) and the monkey (Kawai et al. 1995), in both of which thymic irradiation (TI) has been shown to be essential for the induction of long-term, stable mixed chimerism, TI could be omitted in the swine model and mixed chimerism could still be achieved, albeit at a lower level (Cina et al. 2006). The reason for this discrepancy may be related to the fact that antibody depletion of $\mathrm{T}$ cells is ineffective in the thymus when this depletion is dependent on the usual antibody-de- pendent mechanisms, including complementmediated killing and antibody-dependent cellmediated cytotoxicity (ADCC). However, in the swine model, depletion using the CD3 immunotoxin would not be expected to depend on anything other than the toxin itself. Therefore, depletion of mature $\mathrm{T}$ cells in the thymus may be sufficient using this protocol, even without TI.

By examining many of the parameters of chimerism detectable in the miniature-swine large-animal model, Horner et al. (2006) have attempted to determine which parameters are most indicative of induction of transplantation tolerance by this chimerism. The presence of donor cells in bone marrow, thymus, and various lineages of peripheral blood were examined in a series of 22 HCTrecipients that also received subsequent donor renal allografts without immunosuppression. Bone marrow was assayed for the presence of donor colony-forming units (CFUs) by PCR, thymus by both fluorescenceactivated cell sorting (FACS) analysis on thymic cell suspensions and by Southern blots, and peripheral blood by FACS and by in vitro responsiveness to donor MHC. These comparisons showed that engraftment, as indicated by the presence of donor-derived CFU in the bone marrow and detectable thymic chimerism, was the most reliable predictor of subsequent acceptance of a donor-matched renal allograft, whereas peripheral blood chimerism and in vitro assays of responsiveness were less-accurate predictors, although they were also highly correlated with tolerance (Horner et al. 2006).

\section{STUDIES IN NONHUMAN PRIMATES}

There are significant biological differences between rodents and large animals that are attributable to both genetic and developmental differences. The discrepancy in the ease of tolerance induction between rodents and primates may involve, for example, differential expression of MHC antigens, especially class II (Pescovitz et al. 1984a,b), as well as differences in levels of heterologous memory $\mathrm{T}$ cells depending on whether or not recipients are housed in environmentally controlled conditions (Adams 
et al. 2003a; Wu et al. 2004; Nadazdin et al. 2010). Elucidating these biological differences between species has proved pivotal to the successful extension of basic observations in mice to large animals and humans.

With regard to the induction of mixed chimerism with a nonmyeloablative regimen, earlier murine studies (see above) have shown that stable mixed chimerism and skin allograft tolerance can be consistently achieved across full MHC barriers with a nonmyeloablative conditioning regimen that consisted of low-dose total body irradiation (TBI, 3 Gy), thymic irradiation (7 Gy), and anti-T-cell antibody (Sharabi and Sachs 1989; Sykes and Sachs 2001). The recipient's mature $\mathrm{T}$ cells had to be severely depleted so that newly maturing $\mathrm{T}$ cells would be clonally deleted as they repopulated the Tcell repertoire. However, similar nonmyeloablative conditioning regimens failed to induce stable mixed chimerism in nonhuman primates (NHPs), likely because of the inability to completely deplete mature $\mathrm{T}$ cells. By adding splenectomy and a 1-mo course of cyclosporine to the conditioning regimen, mixed chimerism was found inducible, but only transiently (Kawai et al. 1995; Kimikawa et al. 1997). In subsequent experiments, mixed chimerism was significantly improved by adding CD154 blockade in place of splenectomy, but it still failed to induce stable mixed chimerism (Kawai et al. 2004). Kean and colleagues have also reported difficulty inducing stable chimerism in NHPs with a nonmyeloablative conditioning regimen. In their study, NHP recipients were treated with a busulfan-based conditioning regimen with CD40/CD40L and CD28/B7 blockade but failed to achieve stable mixed chimerism even in MHC-matched pairs (Pescovitz et al. 1984b; Larsen et al. 2010). This difference in chimerism induction between rodents and NHPs is presumably due to the presence of abundant memory $\mathrm{T}$ cells (Tmem) in NHP, which are not present in laboratory mice (Adams et al. 2003a,b). These Tmem are resistant to costimulatory blockade (Valujskikh et al. 2002) and to conventional anti-T-cell antibody treatment (Yamada et al. 2012), which may result in failure to achieve stable mixed chimerism.
Despite an inability to induce stable mixed chimerism in NHPs, we found that renal allograft tolerance was inducible across full $\mathrm{MHC}$ barriers even with transient mixed chimerism, as long as the kidneys were transplanted before the loss of peripheral chimerism (Kawai et al. 1995, 1999, 2004; Kimikawa et al. 1997). Continued survival of the renal allografts after the loss of chimerism suggested that peripheral mechanisms were also operative in tolerant recipients. As detailed below, the renal allograft itself has been shown to play a critical role in the maintenance of tolerance (Seidl et al. 1992).

For induction of renal allograft tolerance, splenectomy was initially thought to be a prerequisite in our conditioning regimen, because recipients consistently developed acute humoral rejection without splenectomy (Kawai et al. 1999, 2004). Because the spleen is the largest single site of lymphoid tissue where close collaboration between antigen-driven Tand B cells occurs (Davis and Bjorkman 1990), splenectomy prevents such $\mathrm{T} / \mathrm{B}$-cell collaboration, especially when T-cell depletion by antibody treatment is not sufficient. Because of the pivotal role of the CD154 (i.e., the CD40 L-CD40) pathway in T- and B-cell responses, it was hypothesized that agents reacting with those molecules might also be able to prevent humoral rejection. By adding a short course of CD154 blockade in place of splenectomy, eight of eight recipients developed improved chimerism, and most recipients survived long term (Kawai et al. 2004). Unfortunately, anti-CD154 mAb is not likely to be available clinically because of its thrombogenic side effects (Kawai et al. 2000); therefore, applications of other costimulatory blockades, such as CTLA-4Ig, are also under current investigation for this purpose.

The conditioning regimen originally used in our laboratories for tolerance induction in NHP required treatment of recipients beginning $6 \mathrm{~d}$ before organ transplantation, which would limit the applicability of this procedure to only living donor allograft recipients. Therefore, we have recently developed a "delayed tolerance" protocol, in which kidney transplantation is performed first, with conventional immunosuppressive therapy, followed by con- 
D.H. Sachs et al.

ditioning and donor bone marrow transplantation (DBMT) at a subsequent time. With this approach, any stable recipient of either living or deceased donor kidney transplantation (KTx) could be a potential candidate, if either fresh (living donor) or cryopreserved (deceased donor) donor bone marrow (DBM) cells were available. In the delayed tolerance protocol, however, induction of mixed chimerism was found to be more difficult, likely because the prior transplanted kidney allograft may have sensitized the recipients before DBMT. We speculated that the faster homeostatic recovery of $\mathrm{CD}^{+}{ }^{+}$Tmem observed in the recipients of the delayed protocol in comparison to the standard protocol may have prevented induction of mixed chimerism. Following the addition of a humanized anti-CD8 mAb, cM-T807 (Schmitz et al. 1999) to the treatment regimen, recipients consistently developed mixed chimerism and achieved renal allograft tolerance (Koyama et al. 2007; Yamada et al. 2012). The timing of DBMT was also found to be critical. Recipients acquired allograft tolerance when DBMT was performed at 4 mo but consistently failed when DBMT was performed at 1 mo after kidney transplantation. Significantly higher inflammatory cytokine levels were detected at $1 \mathrm{mo}$ than at $4 \mathrm{mo}$, suggesting that higher inflammatory responses caused by DBMT conditioning prevented tolerance induction (Yamada et al. 2012).

Studies attempting to extend the mixed chimerism approach to organ allografts other than kidneys (heart, lung, and islet) in cynomolgus monkeys have also been performed in this laboratory. In a heterotopic cardiac allograft model, three of five recipients developed multilineage chimerism, with allograft survivals in these recipients prolonged to 138,428 , and $509 \mathrm{~d}$. Although in vitro assays showed donor-specific hyporesponsiveness, long-term heart allograft recipients eventually developed humoral and cellular immunity against the donor and rejected the grafts, indicating failure to induce full tolerance (Kawai et al. 2002).

Encouraged by our studies in MHC inbred miniature swine (Mezrich et al. 2004), we subsequently tested the effects of heart and kidney cotransplantation in NHP recipients using our mixed chimerism approach. We found that the presence of a kidney allograft consistently conferred stable and long-term tolerance to recipients of cotransplanted heart grafts from the same donors, even with transient chimerism (Tonsho 2012). Critical involvement of the kidney allograft in the maintenance of tolerance was shown by the fact that when the donor kidneys were removed, the heart allografts were rejected soon thereafter. Similar to the heart allograft, islet allograft tolerance was not achieved by induction of transient mixed chimerism. However, an islet allograft was accepted without immunosuppression when islets from the original $\mathrm{BM}$ and kidney donor were transplanted under the renal capsule of the allograft recipient that had previously been rendered tolerant by DBMT (Kawai et al. 2001). These results suggest that the presence of the renal allograft is a prerequisite for the maintenance of tolerance of cotransplanted tissues and organs after the loss of mixed chimerism. Our ultimate goal is to incorporate this yet-to-be-defined "kidney factor" into a novel and clinically relevant tolerance protocol that could induce unresponsiveness to other organ allografts without the requirement for a kidney transplant.

\section{CLINICAL TOLERANCE INDUCTION THROUGH MIXED CHIMERISM}

Although numerous tolerance induction strategies have been reported in rodent models and several have been reported in large animals, clinical renal allograft tolerance has been achieved to date only by induction of mixed or full hematopoietic chimerism. We review here three clinical studies in which such tolerance has been reported.

The Stanford group has developed a total lymphoid irradiation (TLI)-based conditioning regimen to induce renal allograft tolerance with either mixed or full chimerism in HLAidentical kidney transplantation (Millan 2005; Scandling et al. 2008, 2012). This protocol was based on decades of research in rodents, large animals, and clinical studies, attempting to improve the outcomes of HCT for the treatment of 
hematologic malignancies (Slavin et al. 1979; Strober et al. 1989; Millan et al. 2002; Lowsky et al. 2005; Kohrt et al. 2009). Fifteen of 16 patients receiving the Stanford regimen developed persistent mixed chimerism, and eight patients with chimerism lasting $>6$ mo were reported to have been completely withdrawn from immunosuppressive medications, with the longest allograft survival exceeding $3 \mathrm{yr}$. Four patients continued to receive immunosuppressive drugs because of recurrence of focal segmental glomerulosclerosis in one and rejection episodes during the tapering of cyclosporine in the others. The Stanford group also attempted induction of renal allograft tolerance with a similar regimen in HLA-mismatched kidney transplantation (Millan et al. 2002). However, all recipients failed to achieve tolerance, and it was concluded that this protocol, in its current form, did not induce allograft tolerance in HLA-mismatched recipients.

At Massachusetts General Hospital (MGH), a total of seven patients with renal failure secondary to refractory multiple myeloma have received HLA-identical combined kidney and bone marrow transplantation (CKBMT). The first six of these patients were treated on a study funded by the NIAID's Immune Tolerance Network (ITN). These patients received cyclophosphamide (CYP)-based nonmyeloablative conditioning that was based on a mouse model for separating GVHD and GVL (see above). The mouse protocol involved CYP and recipient $\mathrm{T}$ cell depletion plus thymic irradiation in a nonmyeloablative regimen for induction of mixed chimerism, which was followed by delayed DLI (Pelot et al. 1999; Mapara et al. 2002, 2003). Clinical trials in patients with hematologic malignancies showed sufficient safety and anti-tumor efficacy to allow use of the same protocol for renal allograft tolerance induction in multiple myeloma patients with HLA-identical donors (Spitzer et al. 1999, 2011; Buhler et al. 2002; Fudaba et al. 2006). Either transient or durable (mixed or full) chimerism was achieved, and five of seven patients remain alive at the time of this writing. Remission of the myeloma was observed even in some patients with transient chimerism, suggesting a GVL effect despite loss of chimerism, as was subsequently shown in a mouse model (see above) (Rubio et al. 2003, 2005, 2006; Saito et al. 2006). Immunosuppression was successfully withdrawn in all three recipients who had transient chimerism and in one recipient with stable mixed chimerism, with the longest kidney allograft survival now exceeding 14 yr. One patient with transient chimerism subsequently received a second stem cell transplantation from the same donor because of progressive myeloma. She developed stable full chimerism, and, like all other patients with full donor chimerism, she remained thereafter on immunosuppression for GVHD prophylaxis. These observations show that CKBMT with a nonmyeloablative regimen from an HLAmatched donor can be an excellent option for renal failure secondary to myeloma, where no effective treatment option has previously been available.

Shortly after it became clear that renal allograft tolerance could be achieved by this mixed chimerism approach in an HLA-matched setting, a study to extend this approach to HLAmismatched renal transplantation was begun at $\mathrm{MGH}$, also sponsored by the ITN (Kawai et al. 2008). Ten patients received HLA-mismatched CKBMT after conditioning with CYP-based nonmyeloablative conditioning regimens. After acute humoral rejection was observed in patient 3 , the original regimen (NKD03) was modified by adding two doses of pretransplant rituximab (modified NKD03 regimen). Patients 6 to 10 received a further modified conditioning regimen, with four peritransplant doses of rituximab (ITN036). All 10 subjects developed transient chimerism, which became undetectable by Day 21, and no GVHD occurred, meeting a critical safety criterion in patients who had no malignant disease. Immunosuppression was successfully discontinued 8-14 mo posttransplant in seven of 10 patients. Patient 1 has remained well, without rejection for $>10 \mathrm{yr}$. Patient 2 has also remained rejection free for $>9 \mathrm{yr}$, although mycophenolate mofetil (MMF) was added after $7 \mathrm{yr}$ for recurrence of membranoproliferative glomerulonephritis (MPGN), his original disease. Kidney allograft function has remained stable for $>7 \mathrm{yr}$ in patient 4 , al- 
D.H. Sachs et al.

though MMF was instituted at 5 yr because of a histological diagnosis of chronic humoral rejection. Patient 5 remained rejection free for $6 \mathrm{yr}$ despite the development of low levels of DSA after discontinuing immunosuppression (IS). His most recent protocol biopsy at $6.8 \mathrm{yr}$, however, shows minor transplant glomerulopathy (C4d negative), which could indicate the incipient onset of chronic rejection. ITN036-treated patients 6, 7, and 9 successfully discontinued IS and remain stable, without evidence of rejection or DSA for periods of 3-4 yr. Patient 8 returned to dialysis after losing kidney function at 6 mo posttransplantation because of thrombotic microangiopathy. IS was reinstituted in patient 10 when cellular rejection was diagnosed 2 mo after IS withdrawal. His renal function became compromised and he eventually underwent a second kidney transplantation at 3 yr. In contrast to the development of DSA observed in recipients of the modified NKD03 regimen, no DSA has been detected in recipients of the ITN036 regimen, which suggests that prolonged depletion of CD20 ${ }^{+}$B cells adequately controls DSA. "Engraftment syndrome," which causes transient renal dysfunction (Spitzer 2001), was observed in nine of these 10 patients and remains a problem to be solved. Several protocol modifications are planned to overcome this complication, which has not been observed in nonhuman primates treated with a similar protocol (Kawai et al. 1995, 2004). Possible mechanisms of this phenomenon are discussed below.

A third clinical approach has recently been reported by Leventhal et al. (2012) at Northwestern University. These investigators used a conditioning strategy consisting of total body irradiation (200 Gy), fludarabine, and highdose cyclophosphamide, both pre- and postBMT, together with administration of donor hematopoietic stem cells for treatment of eight HLA-mismatched kidney transplant recipients. The conditioning regimen was more intensive than that used in the MGH protocol, and full donor chimerism was achieved in several of these patients, reportedly without GVHD. These results suggest either that the preparative regimen was myeloablative or that donor $\mathrm{T}$ cells in the graft destroyed recipient hematopoiesis via a GVH reaction. Although their protocol has not been fully disclosed, they claim that the administration of novel "tolerogenic $\mathrm{CD}^{+}$ /TCR-facilitating cells (FC)” (Williams 1988; Kaufman et al. 1994) prevented rejection. The criterion for weaning of all maintenance immunosuppression was stated as persistent donor chimerism without GVHD for $1 \mathrm{yr}$. This criterion has apparently been reached in eight of 15 patients in a follow-up study (Leventhal et al. 2013). The highly myelosuppressive nature of the conditioning and/or the potential GVHR associated with the transplant is highlighted by the prolonged neutropenia and thrombocytopenia in these patients, which necessitated support with G-CSF and platelet transfusions (Leventhal et al. 2013).

These results contrast markedly with those reported in patients with hematologic malignancies who received HCT from less extensively mismatched (haploidentical related) donors with a similar regimen and in whom a $34 \%$ incidence of acute GVHD as well as significant chronic GVHD was reported (Luznik et al. 2008; Kasamon et al. 2010). Thus, the Northwestern results, if validated with longer followup and in larger numbers of patients, are unexpected and remarkable. However, significant morbidity due to putative infections occurred in the study (Leventhal et al. 2012), and there are reasons to be concerned that these patients may not regain normal immune incompetence (Strober et al. 2011; Kean and Blazar 2012; Li and Sykes 2012). In this regard, it is noteworthy that the patients in the HLA-mismatched HCT trials at MGH have not suffered from any significant opportunistic infections.

\section{MECHANISTIC STUDIES}

As is discussed above, the durable chimerism achieved in mouse models involving depletion or tolerization with specific deletion of preexisting donor-reactive T cells, ultimately involves central deletion as a major mechanism maintaining long-term tolerance to the donor. In these cases, the tolerance achieved is long-lasting and independent of the presence of other donor organs or tissues. On the other hand, in 
both the NHP models and the clinical studies described above, chimerism has generally been transient. Transient chimerism achieved in the face of only partial depletion of the preexisting T-cell repertoire is unlikely to result in the pure central, deletional form of tolerance achieved in the murine models. As is discussed below, the kidney also seems to play an important role in the achievement of lasting tolerance in primates and humans.

There are several surprising aspects of the clinical outcomes in the myeloma patients that raise important mechanistic questions. Myeloma outcomes were very good overall, and several of the patients achieved prolonged, complete remissions of their myelomas despite achieving only transient chimerism (Fudaba et al. 2006; Spitzer et al. 2011). This, and observations in other patients achieving lymphoma remissions despite transient chimerism with similar regimens (Dey et al. 2005), raised the possibility that initial marrow engraftment followed by rejection, which was evidenced by sensitized anti-donor T-cell responses in some patients (Fudaba et al. 2006), could lead to antitumor responses. Studies in an animal model confirmed this hypothesis (Rubio et al. 2003, 2005, 2006; Saito et al. 2006). The other surprising aspect in these patients was the long-term acceptance of donor kidneys after disappearance of chimerism. In at least some patients, this loss of chimerism was clearly due to rejection, because sensitization to minor histocompatibility antigens (HAs) expressed on hematopoietic cells was evident in vitro (Fudaba et al. 2006). Thus, renal allograft tolerance might be specific for kidney and include a role for the kidney graft itself. Indeed, $\mathrm{T}$ cells from these patients were unresponsive to donor renal tubular epithelial cells (Fudaba et al. 2006), suggesting that tolerance is specific for minor antigens expressed on the kidney graft itself.

Even more evanescent (lasting only a few weeks) chimerism was also observed in all of the recipients (who did not have a malignant disease) of HLA-mismatched CKBMT with the anti-CD2-based regimen (Kawai et al. 2008; Locascio et al. 2010). Loss of chimerism was associated with robust recipient hemato- poiesis, showing that the regimen was truly nonmyeloablative. Because the donors were HLA mismatched, most of these patients had clearly measurable anti-donor alloresponses in vitro before transplant. Remarkably, despite the loss of chimerism, all four of the tolerant patients in the first study showed the progressive development of complete donor-specific unresponsiveness in both mixed lymphocyte response (MLR) and cell-mediated lympholysis (CML) assays. In vitro unresponsiveness to cultured donor renal tubular epithelial cells also developed. Normal anti-third-party alloresponses recovered in all four patients (Kawai et al. 2008; Andreola et al. 2011), suggesting that the state of donor-specific tolerance was systemic. Limiting dilution analyses (LDAs) showed a long-term absence of donor-reactive IL-2-producing cells or CTL precursors, suggesting that eventual tolerance was deletional (Andreola et al. 2011). There is an apparent contradiction between these observations and those in recipients of HLA-identical combined kidney and bone marrow transplants, who sometimes showed sensitization to donor hematopoietic antigens in association with loss of chimerism (Fudaba et al. 2006). Although it might be thought that this indicates that the mechanisms of tolerance differ in the HLAidentical versus the mismatched setting, a more unifying hypothesis is that in both groups, tolerance is restricted to antigens expressed by the kidney. In the HLA-mismatched transplant setting, most of the many different donor HLA/ peptide complexes eliciting strong pretransplant immune responses are likely expressed both on hematopoietic cells and the kidney. Thus, tolerance of the donor kidney would extend to hematopoietic cells, as observed in MLR and CML assays. In the HLA-identical CKBMT recipients, in contrast, complete tolerance to the small number of minor HAs expressed by the kidney could still leave a significant pool of $\mathrm{T}$ cells recognizing minor HAs expressed only on hematopoietic cells, resulting in rejection of the marrow and sensitized in vitro responses to donor alloantigens, as observed (Kraus et al. 2003; Fudaba et al. 2006), whereas the kidney graft is accepted. This "unifying" explanation 
D.H. Sachs et al.

implies tolerance to alloantigens of the kidney in both the HLA-identical and HLA-mismatched CKBMT groups. In the HLA-mismatched setting, the donor-specific unresponsiveness seen in vitro in CKBMT recipients contrasted strikingly with results in patients with hematological malignancies who received a similar haploidentical BMT regimen without a kidney transplant. The latter group tended to have stronger anti-donor than anti-third-party responses following the loss of chimerism (Shaffer et al. 2007), suggesting that the kidney played an active role in the systemic (as evidenced by the MLR, CML, and LDA results) tolerance achieved in the CKBMT recipients.

Indeed, the transient chimerism achieved in the HLA-mismatched CKBMTrecipients makes it difficult to imagine that the long-term tolerance achieved is due to a pure central deletional mechanism. These observations have led us to consider alternative hypotheses. Intragraft levels of the Treg-associated transcription factor FoxP3 relative to Granzyme B mRNA were increased in tolerant patients compared with conventional transplant patients, raising the possibility that regulatory $\mathrm{T}$ cells might play a role in tolerance (Kawai et al. 2008). Tregs are enriched among the peripheral blood $\mathrm{T}$ cells initially present in recipients of this regimen for BMT alone (Shaffer et al. 2007) and in the CKBMT recipients (Fudaba et al. 2006; Andreola et al. 2011). Depletion of Tregs revealed anti-donor responses that were not apparent in unfractionated PBMCs in the first year posttransplant in some, but not all of the patients (Andreola et al. 2011). Although the inconsistency of this observation is unsatisfying, the uniform inability to reveal anti-donor responses with Treg-depleted PBMCs $>1$ yr posttransplant is consistent with a long-term deletional process induced by the "quiescent" kidney graft itself. Alternatively, the relevant Tregs (and possibly donor-reactive effector T cells) may all reside in the graft. We are currently addressing this possibility by expanding $\mathrm{T}$ cells from protocol biopsies from the tolerant CKBMT patients, and preliminary phenotypical data suggest the presence of both Tregs and effector $\mathrm{T}$ cells in the lines we have cultured (B Sprangers, T Mo- rokata, and M Sykes, unpubl.). Studies are in progress to identify the function and specificity of these T cells.

In the second cohort of CKBMT patients, we have performed more detailed phenotypical and kinetic studies on the Tregs that are enriched in the $\mathrm{CD}^{+}{ }^{+} \mathrm{PBMC}$ early posttransplant and on the conventional T cells. Preliminary studies suggest that the early Treg enrichment may reflect a combination of lymphopeniadriven expansion and a possible early wave of thymic Treg emigration (B Sprangers, T Morokata, and M Sykes, unpubl.). Because peripheral APCs recirculate to the thymus and promote tolerance there by both deletional and Tregmediated mechanisms (Donskoy and Goldschneider 2003; Bonasio et al. 2006; Proietto et al. 2008; Hadeiba et al. 2012), it is possible that this early wave of Treg emigration contributes to the tolerance observed.

Several patients in the first, but not the second, cohort of HLA-mismatched CKBMT patients developed alloantibodies to their donors. In light of the donor-specific unresponsiveness detected in vitro, the development of DSA may reflect dysregulated, T-cell-independent B-cell activation as suggested (Porcheray et al. 2009), or, alternatively, may reflect failure to tolerize the indirect T-cell alloresponse. Because the assays discussed above measure predominantly direct alloresponses, studies are in progress to specifically assess anti-donor indirect alloresponses in these patients.

There is less mechanistic data available for tolerance induced by durable chimerism. As mentioned above, a TLI/ATG-based HCT protocol, also supported by safety data obtained in patients with hematological malignancies (Lowsky et al. 2005), has recently been used to achieve renal allograft tolerance in eight patients receiving HLA-identical related donor combined hematopoietic and kidney transplantation (Scandling et al. 2008, 2012). The mechanisms of tolerance in these patients may involve Th2 cytokines secreted by NKT cells, which, along with Tregs, are enriched in these patients. In contrast to patients with transient chimerism, these chimeric recipients do not show sensitization and actually show reduced in vitro 
responses to donor minor HAs (Scandling et al. 2012). Unfortunately, a similar protocol was unsuccessful in the HLA-mismatched setting (Millan et al. 2002; Strober et al. 2004).

\section{CONCLUSIONS}

It has become clear over the past two decades that the usual definition of immunological tolerance as "the specific absence of immune response to an antigen in the absence of immunosuppression" requires modification in the field of transplantation, where it is now clear that tolerance can also result from the presence of a down-regulatory immune response to a transplantation antigen. We can therefore more comprehensively define transplantation tolerance as "the specific absence of a destructive immune response to a transplanted tissue or organ in the absence of immunosuppression." This definition incorporates both central, deletional tolerance mechanisms and peripheral, downregulatory tolerance mechanisms. Interestingly, both sets of mechanisms appear to be relevant to the induction of tolerance through mixed chimerism, as summarized in this review.

We have attempted here to provide a brief overview of the current status of tolerance induction through mixed chimerism in smalland large-animal models as well as in the clinic. Although it is clear that this modality has been successful in inducing tolerance in both small and large animals, it is also clear that both the methodology for induction of chimerism and the mechanism by which tolerance is induced have been different in different species. Probably the most important element required for achieving mixed chimerism through the induction of purely central, deletional tolerance is complete depletion of mature, donor-reactive $\mathrm{T}$ cells as a consequence of the preparative regimen. Thus, even in mice, where antibody reagents capable of depleting all mature $\mathrm{T}$ cells peripherally are available, the addition of thymic irradiation was required to achieve longlasting, deletional tolerance (Sharabi and Sachs 1989), because mechanisms for antibody-mediated depletion appear not to be effective in the thymus (Nikolic et al. 2001). Consistent with this hypothesis are the data in miniature swine, in which durable mixed chimerism was possible without thymic irradiation only when an immunotoxin was used for T-cell depletion, presumably allowing depletion of thymic $\mathrm{T}$ cells directly by the toxin rather than by the usual antibody-mediated mechanisms (Huang et al. 1999b, 2000). Models for achieving durable mixed chimerism without complete depletion of mature, donor-reactive $\mathrm{T}$ cells have generally relied on the addition of costimulatory blockade to the preparative regimen. Costimulatory blockade with BMT promotes anergy followed by deletion of pre-existing donor-reactive T cells, both in the periphery (Kurtz et al. 2004; Fehr et al. 2005) and the thymus (J Kurtz and M Sykes, unpubl.).

In the primate models we have discussed, complete depletion of mature $\mathrm{T}$ cells has not been achieved, and mixed chimerism has been transient (Kawai et al. 2011). Nevertheless, tolerance has been established, undoubtedly through the generation of regulatory $\mathrm{T}$ cells capable of down-regulating the alloaggressive response that might otherwise have resulted from activation of the residual $\mathrm{T}$ cells. To achieve tolerance of a donor kidney, it had to be transplanted while mixed chimerism was still detectable in the recipient animal, and continued presence of the donor kidney was found to be essential to maintenance of the Treg and to maintenance of tolerance. With the possible exception of recent studies from Northwestern (Leventhal et al. 2012), in which durable full chimerism across HLA barriers was reported, induction of tolerance of mismatched organ allografts in the clinic has, as in NHP models, involved transient mixed chimerism.

Because the ultimate goal of using mixed chimerism for tolerance induction is longterm survival of organ allografts without the need for chronic immunosuppression, it is not clear whether attaining this goal through central versus peripheral mechanisms is as important practically as it may seem from a theoretical viewpoint. Indeed, although tolerance due to the absence of alloreactive T cells achieved centrally might appear to have an advantage in being more complete and less susceptible to dis- 
D.H. Sachs et al.

ruption by inflammatory stimuli, it could have disadvantages over peripheral tolerance because of the absence of mechanisms to down-regulate residual alloreactive $T$ cells that, like $T$ cells causing autoimmunity, may become activated and expand in the peripheral environment. In addition, Tregs are thought to be responsible for the phenomenon of linked suppression, which could permit down-regulation of responses to tissue-specific antigens present on cells of organ allografts but not on the hematopoietic stem cells used to produce mixed chimerism. In any case, it appears that mixed chimerism can be intimately associated with both forms of tolerance and that a combination of both may be the best way of achieving our long-term goals.

\section{ACKNOWLEDGMENTS}

We gratefully acknowledge Rebecca A. Wark for expert editorial assistance.

\section{REFERENCES}

Adams AB, Pearson TC, Larsen CP. 2003a. Heterologous immunity: An overlooked barrier to tolerance. Immunol Rev 196: $147-160$.

Adams AB, Williams MA, Jones TR, Shirasugi N, Durham MM, Kaech SM, Wherry EJ, Onami T, Lanier JG, Kokko KE, et al. 2003b. Heterologous immunity provides a potent barrier to transplantation tolerance. J Clin Invest 111: 1887-1895.

Andreola G, Chittenden M, Shaffer J, Cosimi AB, Kawai T, Cotter P, Dey B, Tolkoff-Rubin N, Preffer F, Bonnefoix T, et al. 2011. Mechanisms of donor-specific tolerance in recipients of haploidentical combined bone marrow/ kidney transplantation. Am J Transplant 11: 1236-1247.

Aversa F, Tabilio A, Velardi A, Cunningham I, Terenzi A Falzetti F, Ruggeri L, Barbabietoloa G, Aristei C, Latini P, et al. 1998. Treatment of high-risk acute leukemia with $\mathrm{T}$ cell-depleted stem cells from related donors with one fully mismatched haplotype. New Engl J Med 339: 1186-1193.

Bemelman F, Honey K, Adams E, Cobbold S, Waldmann H 1998. Bone marrow transplantation induces either clonal deletion or infectious tolerance depending on the dose. $J$ Immunol 160: 2645-2648.

Bigenzahn S, Blaha P, Koporc Z, Pree I, Selzer E, Bergmeister H, Wrba F, Heusser C, Wagner K, Muehlbacher F, et al 2005. The role of non-deletional tolerance mechanisms in a murine model of mixed chimerism with costimulation blockade. Am J Transplant 5: 1237-1247.

Bonasio R, Scimone ML, Schaerli P, Grabie N, Lichtman AH, von Andrian UH. 2006. Clonal deletion of thymocytes by circulating dendritic cells homing to the thymus. Nat Immunol 7: 1092-1100.
Bordignon C, Keever CA, Small TN, Flomenberg N, Dupont B, O’Reilly RJ, Kernan NA. 1989. Graft failure after T-celldepleted human leukocyte antigen identical marrow transplants for leukemia: II. In vitro analyses of host effector mechanisms. Blood 74: 2237-2243.

Buhler LH, Spitzer TR, Sykes M, Sachs DH, Delmonico FL, Tolkoff-Rubin N, Saidman SL, Sackstein R, McAfee S, Dey B, et al. 2002. Induction of kidney allograft tolerance after transient lymphohematopoietic chimerism in patients with multiple myeloma and end-stage renal disease. Transplantation 74: 1405-1409.

Chakraverty R, Cote D, Buchli J, Cotter P, Hsu R, Zhao G, Sachs T, Psitilides C, Bronson R, Means T, et al. 2006a. An inflammatory checkpoint regulates recruitment of graftversus-host-reactive T cells to peripheral tissues. $J$ Exp Med 203: 2021-2031.

Chakraverty R, Eom HS, Sachs J, Buchli J, Cotter P, Hsu R, Zhao G, Sykes M. 2006b. Host MHC class $\mathrm{II}^{+}$antigenpresenting cells and CD4 cells are required for CD8-mediated graft-versus-leukemia responses following delayed donor leukocyte infusions. Blood 108: 2106-2113.

Cina RA, Wikiel KJ, Lee PW, Cameron AM, Hettiarachy S, Rowland H, Goodrich J, Colby C, Spitzer TR, Neville DM Jr, et al. 2006. Stable multilineage chimerism without graft versus host disease following nonmyeloablative haploidentical hematopoietic cell transplantation. Transplantation 81: 1677-1685.

Cobbold SP, Qin S, Waldmann H. 1990. Reprogramming the immune system for tolerance with monoclonal antibodies. Sem Immunol 2: 377-387.

Cosimi AB, Sachs DH. 2004. Mixed chimerism and transplantation tolerance. Transplantation 77: 943-946.

Davis MM, Bjorkman PJ. 1990. A model for T cell receptor and MHC/peptide interaction. Adv Exp Med Biol 254: $13-16$.

Dey BR, MCafee S, Colby C, Cieply K, Caron M, Saidman S, Preffer F, Shaffer J, Tarbell N, Sackstein R, et al. 2005. Anti-tumor response despite loss of donor chimerism in patients treated with nonmyeloablative conditioning and allogeneic stem cell transplantation. $\mathrm{Br}$ J Haematol 128: $351-359$.

Domenig C, Sanchez-Fueyo A, Kurtz J, Alexopoulos AP, Mariat C, Sykes M, Strom TB, Zheng XX. 2005. Roles of deletion and regulation in creating mixed chimerism and allograft tolerance using a nonlymphoablative irradiation-free protocol. J Immunol 175: 51-60.

Donskoy E, Goldschneider I. 2003. Two developmentally distinct populations of dendritic cells inhabit the adult mouse thymus: Demonstration by differential importation of hematogenous precursors under steady state conditions. J Immunol 170: 3514-3521.

Fehr T, Takeuchi Y, Kurtz J, Sykes M. 2005. Early regulation of CD8 $\mathrm{T}$ cell alloreactivity by $\mathrm{CD} 4{ }^{+} \mathrm{CD} 25^{-} \mathrm{T}$ cells in recipients of anti-CD154 antibody and allogeneic BMT is followed by rapid peripheral deletion of donor-reactive $\mathrm{CD}^{+} \mathrm{T}$ cells, precluding a role for sustained regulation. Eur J Immunol 35: 2679-2690.

Fehr T, Haspot F, Mollov J, Chittenden M, Hogan T, Sykes M. 2008. Alloreactive CD8 T cell tolerance requires recipient B cells, dendritic cells and MHC class II. J Immunol 181: $165-173$. 
Fehr T, Lucas CL, Kurtz J, Onoe T, Zhao G, Hogan T, Vallot C, Rao A, Sykes M. 2010. A CD8 T cell-intrinsic role for the calcineurin-NFAT pathway for tolerance induction in vivo. Blood 115: 1280-1287.

Fleischhauer K, Kernan NA, O’Reilly RJ, Dupont B, Yang SY 1990. Bone marrow-allograft rejection by T lymphocytes recognizing a single amino acid difference in HLA-B44. New Engl J Med 323: 1818-1822.

Fuchimoto Y, Yamada K, Shimizu A, Yasumoto A, Sawada T, Huang CH, Sachs DH. 1999. Relationship between chimerism and tolerance in a kidney transplantation model. J Immunol 162: 5704-5711.

Fuchimoto Y, Huang CA, Yamada K, Shimizu A, Kitamura H, Colvin RB, Ferrara V, Murphy MC, Sykes M, WhiteScharf M, et al. 2000. Mixed chimerism and tolerance without whole body irradiation in a large animal model. J Clin Invest 105: 1779-1789.

Fudaba Y, Spitzer TR, Shaffer J, Kawai T, Fehr T, Delmonico F, Preffer F, Tolkoff-Rubin N, Dey BR, Saidman SL, et al. 2006. Myeloma responses and tolerance following combined kidney and nonmyeloablative marrow transplantation: In vivo and in vitro analyses. Am J Transplant 6: 2121-2133.

Guzzetta PC, Sundt TM, Suzuki T, Mixon A, Rosengard BR, Sachs DH. 1991. Induction of kidney transplantation tolerance across MHC barriers by bone marrow transplantation in miniature swine. Transplantation 51: 862 866.

Hadeiba H, Lahl K, Edalati A, Oderup C, Habtezion A, Pachynski R, Nguyen L, Ghodsi A, Adler S, Butcher EC. 2012. Plasmacytoid dendritic cells transport peripheral antigens to the thymus to promote central tolerance. Immunity 36: 438-450.

Hanekamp JS, Duran-Struuck R, Sachs DH. 2011. Transplantation in miniature swine. In The minipig in biomedical research (ed. McAnulty PA), pp. 357-372. Taylor \& Francis, London, 2011.

Haspot F, Fehr T, Gibbons C, Zhao G, Hogan T, Honjo T, Freeman GJ, Sykes M. 2008. Peripheral deletional tolerance of alloreactive CD8 but not CD4 cells is dependent on the PD-1/PD-L1 pathway. Blood 112: 2149-2155.

Hayashi H, LeGuern C, Sachs DH, Sykes M. 1996. Alloresistance to $\mathrm{K}$ locus mismatched bone marrow engraftment is mediated entirely by $\mathrm{CD} 4^{+}$and $\mathrm{CD} 8^{+} \mathrm{T}$ cells. Bone Marrow Transplant 18: 285-292.

Haynes BF, Markert ML, Sempowski GD, Patel DD, Hale LP. 2000. The role of the thymus in immune reconstitution in aging, bone marrow transplantation, and HIV-1 infection. Annu Rev Immunol 18: 529-560.

Helg C, Chapuis B, Bolle JF, Morel P, Salomon D, Roux E, Antonioli V, Jeannet M, Leski M. 1994. Renal transplantation without immunosuppression in a host with tolerance induced by allogeneic bone marrow transplantation. Transplantation 58: 1420-1422.

Horner BM, Cina RA, Wikiel KJ, Lima B, Ghazi A, Lo DP, Yamada K, Sachs DH, Huang CA. 2006. Predictors of organ allograft tolerance following hematopoietic cell transplantation. Am J Transplant 6: 2894-2902.

Huang CA, Lorf T, Arn JS, Koo GC, Blake T, Sachs DH. 1999a. Characterization of a monoclonal anti-porcine CD3 antibody. Xenotransplantation 6: 201-212.
Huang CA, Yamada K, Murphy MC, Shimizu A, Colvin RB, Neville DMJ, Sachs DH. 1999b. In vivo T cell depletion in miniature swine using the swine $\mathrm{CD} 3$ immunotoxin, pCD3-CRM9. Transplantation 68: 855-860.

Huang CA, Fuchimoto Y, Scheier-Dolberg R, Murphy MC, Neville DMJ, Sachs DH. 2000. Stable mixed chimerism and tolerance using a nonmyeloablative preparative regimen in a large-animal model. J Clin Invest 105: 173-181.

Ildstad ST, Sachs DH. 1984. Reconstitution with syngeneic plus allogeneic or xenogeneic bone marrow leads to specific acceptance of allografts or xenografts. Nature 307: $168-170$.

Ildstad ST, Wren SM, Bluestone JA, Barbieri SA, Sachs DH. 1985. Characterization of mixed allogeneic chimeras. Immunocompetence, in vitro reactivity, and genetic specificity of tolerance. J Exp Med 162: 231-244.

Ildstad ST, Wren SM, Bluestone JA, Barbieri SA, Stephany D, Sachs DH. 1986. Effect of selective T cell depletion of host and/or donor bone marrow on lymphopoietic repopulation, tolerance, and graft-vs-host disease in mixed allogeneic chimeras $(\mathrm{B} 10+\mathrm{B} 10 . \mathrm{D} 2 \rightarrow \mathrm{B} 10)$. J Immunol 136: $28-33$.

Ito H, Kurtz J, Shaffer J, Sykes M. 2001. CD4 T cell-mediated alloresistance to fully MHC-mismatched allogeneic bone marrow engraftment is dependent on CD40-CD40 L interactions, and lasting $\mathrm{T}$ cell tolerance is induced by bone marrow transplantation with initial blockade of this pathway. J Immunol 166: 2970-2981.

Jacobsen N, Taaning E, Ladefoged J, Kristensen JK, Pedersen FK. 1994. Tolerance to an HLA-B,DR disparate kidney allograft after bone-marrow transplantation from same donor. Lancet 343: 800.

Kasamon YL, Luznik L, Leffell MS, Kowalski J, Tsai HL, Bolanos-Meade J, Morris LE, Crilley PA, O’Donnell PV, Rossiter N, et al. 2010. Nonmyeloablative HLA-haploidentical bone marrow transplantation with high-dose posttransplantation cyclophosphamide: Effect of HLA disparity on outcome. Biol Blood Marrow Transplant 16: $482-489$.

Kaufman CL, Colson YL, Wren SM, Watkins S, Simmons RL, Ildstad ST. 1994. Phenotypic characterization of a novel bone marrow-derived cell that facilitates engraftment of allogeneic bone marrow stem cells. Blood 84: 2436-2446.

Kawai T, Cosimi AB, Colvin RB, Powelson J, Eason J, Kozlowski T, Sykes M, Monroy R, Tanaka M, Sachs DH. 1995. Mixed allogeneic chimerism and renal allograft tolerance in cynomolgus monkeys. Transplantation 59: 256-262.

Kawai T, Poncelet A, Sachs DH, Mauiyyedi S, Boskovic S, Wee SL, Ko DS, Bartholomew A, Kimikawa M, Hong HZ, et al. 1999. Long-term outcome and alloantibody production in a non-myeloablative regimen for induction of renal allograft tolerance. Transplantation 68: 1767-1775.

Kawai T, Andrews D, Colvin RB, Sachs DH, Cosimi AB. 2000. Thromboembolic complications after treatment with monoclonal antibody against CD40 ligand [letter]. Nat Med 6: 114.

Kawai T, Sogawa H, Koulmanda M, Smith RN, O'Neil JJ, Wee SL, Boskovic S, Sykes M, Colvin RB, Sachs DH, et al. 2001. Long-term islet allograft function in the absence of chronic immunosuppression: A case report of a nonhu- 
D.H. Sachs et al.

man primate previously made tolerant to a renal allograft from the same donor. Transplantation 72: 351-354.

Kawai T, Cosimi AB, Wee SL, Houser S, Andrews D, Sogawa H, Phelan J, Boskovic S, Nadazdin O, Abrahamian G, et al. 2002. Effect of mixed hematopoietic chimerism on cardiac allograft survival in cynomolgus monkeys. Transplantation 73: $1757-1764$.

Kawai T, Sogawa H, Boskovic S, Abrahamian G, Smith RN, Wee SL, Andrews D, Nadazdin O, Koyama I, Sykes M, et al. 2004. CD154 blockade for induction of mixed chimerism and prolonged renal allograft survival in nonhuman primates. Am J Transplant 4: 1391-1398.

Kawai T, Cosimi AB, Spitzer TR, Tolkoff-Rubin N, Suthanthiran M, Saidman SL, Shaffer J, Preffer FI, Ding R, Sharma V, et al. 2008. HLA-mismatched renal transplantation without maintenance immunosuppression. New Engl J Med 358: 353-361.

Kawai T, Cosimi AB, Sachs DH. 2011. Preclinical and clinical studies on the induction of renal allograft tolerance through transient mixed chimerism. Curr Opin Organ Transplant 16: $366-371$.

Kean LS, Blazar BR. 2012. Cooking up tolerance: Has a new recipe been created? Am J Transplant 12: 1667-1669.

Kernan NA, Flomenberg N, Dupont B, O'Reilly RJ. 1987. Graft rejection in recipients of T-cell-depleted HLA-nonidentical marrow transplants for leukemia. Transplantation 43: 842-847.

Khan A, Tomita Y, Sykes M. 1996. Thymic dependence of loss of tolerance in mixed allogeneic bone marrow chimeras after depletion of donor antigen. Peripheral mechanisms do not contribute to maintenance of tolerance. Transplantation 62: 380-387.

Kimikawa M, Sachs DH, Colvin RB, Bartholomew A, Kawai T, Cosimi AB. 1997. Modifications of the conditioning regimen for achieving mixed chimerism and donor-specific tolerance in cynomolgus monkeys. Transplantation 64: 709-716.

Kohrt HE, Turnbull BB, Heydari K, Shizuru JA, Laport GG, Miklos DB, Johnston LJ, Arai S, Weng WK, Hoppe RT, et al. 2009. TLI and ATG conditioning with low risk of graftversus-host disease retains antitumor reactions after allogeneic hematopoietic cell transplantation from related and unrelated donors. Blood 114: 1099-1109.

Koyama I, Nadazdin O, Boskovic S, Ochiai T, Smith RN, Sykes M, Sogawa H, Murakami T, Strom TB, Colvin RB, et al. 2007. Depletion of CD8 memory T cells for induction of tolerance of a previously transplanted kidney allograft. Am J Transplant 7: 1055-1061.

Kraus AB, Shaffer J, Toh HC, Preffer F, Dombkowski D, Saidman S, Colby C, George R, MCafee S, Sackstein R, et al. 2003. Early host CD8 T-cell recovery and sensitized anti-donor IL-2-producing and cytolytic T-cell responses associated with marrow graft rejection following nonmyeloablative bone marrow transplantation. Exp Hematol 31: 609-621.

Kurtz J, Ito H, Wekerle T, Shaffer J, Sykes M. 2001. Mechanisms involved in the establishment of tolerance through costimulatory blockade and BMT: Lack of requirement for CD40 L-mediated signaling for tolerance or deletion of donor-reactive $\mathrm{CD} 4^{+}$cells. Am J Transplant 1: 339349 .
Kurtz J, Shaffer J, Anosova N, Benichou G, Sykes M. 2004. Mechanisms of early peripheral CD4 $\mathrm{T}$ cell tolerance induction by anti-CD154 monoclonal antibody and allogeneic bone marrow transplantation: Evidence for anergy and deletion, but not regulatory cells. Blood 103: 43364343.

Larsen CP, Page A, Linzie KH, Russell M, Deane T, Stempora L, Strobert E, Penedo MC, Ward T, Wiseman R, et al. 2010. An MHC-defined primate model reveals significant rejection of bone marrow after mixed chimerism induction despite full MHC matching. Am J Transplant 10: $2396-2409$.

Leventhal J, Abecassis M, Miller J, Gallon L, Ravindra K, Tollerud DJ, King B, Elliott MJ, Herzig G, Herzig R, et al. 2012. Chimerism and tolerance without GVHD or engraftment syndrome in HLA-mismatched combined kidney and hematopoietic stem cell transplantation. Sci Transl Med 4: 124ra28.

Leventhal J, Abecassis M, Miller J, Gallon L, Tollerud D, Elliott MJ, Bozulic LD, Houston C, Sustento-Reodica N, Ildstad ST. 2013. Tolerance induction in HLA disparate living donor kidney transplantation by donor stem cell infusion: Durable chimerism predicts outcome. Transplantation 95: 169-176.

Li HW, Sykes M. 2012. Emerging concepts in haematopoietic cell transplantation. Nat Rev Immunol 12: $403-$ 416.

Li HW, Sachs J, Pichardo C, Bronson R, Zhao G, Sykes M. 2012. Nonalloreactive T cells prevent donor lymphocyte infusion-induced graft-versus-host disease by controlling microbial stimuli. J Immunol 189: 5572-5581.

Locascio SA, Morokata T, Chittenden M, Preffer FI, Dombkowski DM, Andreola G, Crisalli K, Kawai T, Saidman SL, Spitzer TR, et al. 2010. Mixed chimerism, lymphocyte recovery, and evidence for early donor-specific unresponsiveness in patients receiving combined kidney and bone marrow transplantation to induce tolerance. Transplantation 90: 1607-1615.

Lowsky R, Takahashi T, Liu YP, Dejbakhsh-Jones S, Grumet FC, Shizuru JA, Laport GG, Stockerl-Goldstein KE, Johnston LJ, Hoppe RT, et al. 2005. Protective conditioning for acute graft-versus-host disease. N Engl J Med 353: 13211331.

Lucas CL, Workman CJ, Beyaz S, Locascio S, Zhao G, Vignali DA, Sykes M. 2011. LAG-3, TGF- $\beta$, and cell-intrinsic PD1 inhibitory pathways contribute to CD8 but not CD4 Tcell tolerance induced by allogeneic BMT with antiCD40 L. Blood 117: 5532-5540.

Lunney JK, Pescovitz MD. 1987. Phenotypic and functional characterization of pig lymphocyte populations. Vet Immunol Immunopathol 17: 135-144.

Lunney JK, Sachs DH. 1995. The swine leukocyte antigen (SLA) complex. In Transplantation immunology (ed. Bach FH, Auchincloss Jr H), pp. 339-345. Wiley, New York.

Luznik L, O’Donnell PV, Symons HJ, Chen AR, Leffell MS, Zahurak M, Gooley TA, Piantadosi S, Kaup M, Ambinder RF, et al. 2008. HLA-haploidentical bone marrow transplantation for hematologic malignancies using nonmyeloablative conditioning and high-dose, posttransplantation cyclophosphamide. Biol Blood Marrow Transplant 14: 641-650. 
Manilay JO, Pearson DA, Sergio JJ, Swenson KG, Sykes M. 1998. Intrathymic deletion of alloreactive T cells in mixed bone marrow chimeras prepared with a nonmyeloablative conditioning regimen. Transplantation 66: 96-102.

Mapara MY, Kim YM, Wang SP, Bronson R, Sachs DH, Sykes M. 2002. Donor lymphocyte infusions mediate superior graft-versus-leukemia effects in mixed compared to fully allogeneic chimeras: A critical role for host antigen-presenting cells. Blood 100: 1903-1909.

Mapara MY, Kim YM, Marx J, Sykes M. 2003. DLI-mediated GVL effects in mixed chimeras established with a nonmyeloablative conditioning regimen: Extinction of GVL effects coincides with loss of alloreactive cells following conversion to full donor chimerism. Transplantation $\mathbf{7 6}$ : 297-305.

Martin PJ, Hansen JA, Buckner CD, Sanders JE, Deeg HJ, Stewart P, Appelbaum FR, Clift R, Fefer A, Witherspoon $\mathrm{RP}$, et al. 1985. Effects of in vitro depletion of T cells in HLA-identical allogeneic marrow grafts. Blood 66: 664672.

Martin PJ, Hansen JA, Torok-Storb B, Durnam D, Przepiorka D, O'Quigley J, Sanders J, Sullivan KM, Witherspoon RP, Deeg HJ, et al. 1988. Graft failure in patients receiving T cell-depleted HLA-identical allogeneic marrow transplants. Bone Marrow Transplant 3: 445-456.

Mezrich J, Yamada K, Sachs DH, Madsen JC. 2004. Regulatory $\mathrm{T}$ cells generated by the kidney may mediate the beneficial immune effects of combining kidney with heart transplantation. Surgery 135: 473-478.

Millan MT. 2005. Studies of tolerance and chimerism after combined blood stem cell and kidney transplantation in humans. Am J Transplant 5(Suppl): 544.

Millan MT, Shizuru JA, Hoffmann P, Dejbakhsh-Jones S, Scandling JD, Grumet FC, Tan JC, Salvatierra O, Hoppe RT, Strober S. 2002. Mixed chimerism and immunosuppressive drug withdrawal after HLA-mismatched kidney and hematopoietic progenitor transplantation. Transplantation 73: $1386-1391$.

Mollov JL, Lucas CL, Haspot F, Kurtz J, Gaspar C, Guzman A, Sykes M. 2010. Recipient dendritic cells, but not B cells, are required antigen-presenting cells for peripheral alloreactive $\mathrm{CD} 8^{+} \mathrm{T}$ cell tolerance. Am J Transplant 10: $518-526$.

Nadazdin O, Boskovic S, Murakami T, O'Connor DH, Wiseman RW, Karl JA, Tuscher JJ, Sachs DH, Madsen JC, Tocco G, et al. 2010. Phenotype, distribution and alloreactive properties of memory $\mathrm{T}$ cells from cynomolgus monkeys. Am J Transplant 10: 1375-1384.

Nash K, Chang Q, Watts A, Treter S, Oravec G, Ferrara V, Buhler L, Basker M, Gojo S, Sachs DH, et al. 1999. Peripheral blood progenitor cell mobilization and leukapheresis in pigs. Lab Anim Sci 49: 645-649.

Neville DMJ, Scharff J, Hu HZ, Rigaut K, Shiloach J, Slingerland W, Jonker M. 1996. A new reagent for the induction of T-cell depletion, anti-CD3-CRM9. J Immunother Emphasis Tumor Immunol 19: 85-92.

Nikolic B, Khan A, Sykes M. 2001. Induction of tolerance by mixed chimerism with nonmyeloblative host conditioning: The importance of overcoming intrathymic alloresistance. Biol Blood Marrow Transplant 7: 144-153.

Pelot MR, Pearson DA, Swenson K, Zhao G, Sachs J, Yang YG, Sykes M. 1999. Lymphohematopoietic graft-vs-host reactions can be induced without graft-vs-host disease in murine mixed chimeras established with a cyclophosphamide-based non-myeloablative conditioning regimen. Biol Blood Marrow Transplant 5: 133-143.

Pennington LR, Lunney JK, Sachs DH. 1981. Transplantation in miniature swine. VIII. Recombination within the major histocompatibility complex of miniature swine. Transplantation 31: 66-71.

Pennington LR, Sakamoto K, Popitz-Bergez FA, Pescovitz MD, McDonough MA, MacVittie TJ, Gress RE, Sachs DH. 1988. Bone marrow transplantation in miniature swine. I: Development of the model. Transplantation 45: $21-26$

Pescovitz MD, Sachs DH, Lunney JK, Hsu SM. 1984a. Localization of class II MHC antigens on porcine renal vascular endothelium. Transplantation 37: 627-630.

Pescovitz MD, Thistlethwaite JR Jr, Auchincloss H Jr, Ildstad ST, Sharp TG, Terrill R, Sachs DH. 1984b. Effect of class II antigen matching on renal allograft survival in miniature swine. J Exp Med 160: 1495-1508.

Pescovitz MD, Hsu SM, Katz SI, Lunney JK, Shimada S, Sachs Dh. 1990. Characterization of a porcine CD1-specific $\mathrm{mAb}$ that distinguishes $\mathrm{CD} 4 / \mathrm{CD} 8$ double-positive thymic from peripheral T lymphocytes. Tissue Antigens 35: $151-156$.

Pescovitz MD, Book BK, Aasted B, Dominguez J, Ezguerra A, Trebichavsky I, Novikov B, Valpotic I, Neilson J, Arn S, et al. 1998. Analyses of monoclonal antibodies reacting with porcine CD3: Results from the Second International Swine CD Workshop. Vet Immunol Immunopathol 60: 261-268.

Popitz-Bergez FA, Sakamoto K, Pennington LR, Pescovitz MD, McDonough MA, MacVittie TJ, Gress RE, Sachs DH. 1988. Bone marrow transplantation in miniature swine. II. Effect of selective genetic differences on marrow engraftment and recipient survival. Transplantation 45: $27-31$.

Porcheray F, Wong W, Saidman SL, De Vito J, Girouard TC Chittenden M, Shaffer J, Tolkoff-Rubin N, Dey BR, Spitzer TR, et al. 2009. B-cell immunity in the context of Tcell tolerance after combined kidney and bone marrow transplantation in humans. Am J Transplant 9: $2126-$ 2135.

Proietto AI, van Dommelen S, Zhou P, Rizzitelli A, D’Amico A, Steptoe RJ, Naik SH, Lahoud MH, Liu Y, Zheng P, et al 2008. Dendritic cells in the thymus contribute to T-regulatory cell induction. Proc Natl Acad Sci 105: 19869 19874.

Rubio MT, Kim YM, Sachs T, Mapara M, Zhao G, Sykes M. 2003. Anti-tumor effect of donor marrow graft rejection induced by recipient leukocyte infusions in mixed chimeras prepared with nonmyeloablative conditioning: Critical role for recipient-derived IFN- $\gamma$. Blood 102: 2300-2307.

Rubio MT, Saito TI, Kattelman K, Zhao G, Buchli J, Sykes M. 2005. Mechanisms of the anti-tumor responses and hostversus graft reactions induced by recipient leukocyte infusions in mixed chimeras prepared with nonmyeloablative conditioning: A critical role for recipient $\mathrm{CD}^{+}{ }^{+} \mathrm{T}$ cells and recipient leukocyte infusion-derived IFN- $\gamma$ producing $\mathrm{CD}^{+} \mathrm{T}$ cells. J Immunol 175: 665-676. 
D.H. Sachs et al.

Rubio MT, Zhao G, Buchli J, Chittenden M, Sykes M. 2006. Role of indirect allo- and autoreactivity in anti-tumor responses induced by recipient leukocyte infusions (RLI) in mixed chimeras prepared with nonmyeloablative conditioning. Clin Immunol 120: 33-44.

Sachs DH. 1992. MHC homozygous miniature swine. In Swine as models in biomedical research (ed Swindle MM et al.), pp. 3-15. Iowa State University Press, Ames, IA.

Sachs DH. 1994. The pig as a potential xenograft donor. Vet Immunol Immunopathol 43: 185-191.

Sachs DH. 2003. Tolerance: Of mice and men. J Clin Invest 111: $1819-1821$

Saito TI, Rubio MT, Sykes M. 2006. Clinical relevance of recipient leukocyte infusion as antitumor therapy following nonmyeloablative allogeneic hematopoietic cell transplantation. Exp Hematol 34: 1271-1277.

Sakamoto K, Pennington LR, Popitz-Bergez FA, Pescovitz MD, Gress RE, McDonough MA, Shimada S, Katz SI, Sachs DH. 1987. Swine GVHD model and the effect of $\mathrm{T}$ cell depletion of marrow by monoclonal antibodies. Prog Bone Marrow Transplant 449-453.

Sakamoto K, Sachs DH, Shimada S, Popitz-Bergez FA, Pennington LR, Pescovitz MD, McDonough MA, MacVittie TJ, Katz SI, Gress RE. 1988. Bone marrow transplantation in miniature swine. III. Graft-versus-host disease and the effect of T cell depletion of marrow. Transplantation 45: 869-875.

Sayegh MH, Fine NA, Smith JL, Rennke HG, Milford EL, Tilney NL. 1991. Immunologic tolerance to renal allografts after bone marrow transplants from the same donors. Ann Intern Med 114: 954-955.

Scandling JD, Busque S, Dejbakhsh-Jones S, Benike C, Millan MT, Shizuru JA, Hoppe RT, Lowsky R, Engleman EG, Strober S. 2008. Tolerance and chimerism after renal and hematopoietic-cell transplantation. $N$ Engl J Med 358: $362-368$

Scandling JD, Busque S, Dejbakhsh-Jones S, Benike C, Sarwal M, Millan MT, Shizuru JA, Lowsky R, Engleman EG, Strober S. 2012. Tolerance and withdrawal of immunosuppressive drugs in patients given kidney and hematopoietic cell transplants. Am J Transplant 12: 1133-1145.

Schmitz JE, Simon MA, Kuroda MJ, Lifton MA, Ollert MW, Vogel CW, Racz P, Tenner-Racz K, Scallon BJ, Dalesandro $\mathrm{M}$, et al. 1999. A nonhuman primate model for the selective elimination of $\mathrm{CD}^{+}$lymphocytes using a mousehuman chimeric monoclonal antibody. Am J Pathol 154: 1923-1932.

Seidl C, Saraiya C, Osterweil Z, Fu YP, Lee IS. 1992. Genetic complexity of regulatory mutants defective for HLA class II gene expression. J Immunol 148: 1576-1584.

Shaffer J, Villard J, Means TK, Alexander S, Dombkowski D, Dey BR, McAffee S, Ballen KK, Saidman S, Preffer FI, et al. 2007. Regulatory T-cell recovery in recipients of haploidentical nonmyeloablative hematopoietic cell transplantation with a humanized anti-CD2 mAb, MEDI507, with or without fludarabine. Exp Hematol 35: $1140-1152$.

Sharabi Y, Sachs DH. 1989. Mixed chimerism and permanent specific transplantation tolerance induced by a nonlethal preparative regimen. J Exp Med 169: 493-502.

Sharabi Y, Sachs DH, Sykes M. 1992. T cell subsets resisting induction of mixed chimerism across various histocom- patibility barriers. In Progress in immunology. VIII. Proceedings of the Eighth International Congress of Immunology, Budapest (ed. Gergely J, et al.), pp. 801-805. Springer-Verlag, Heidelberg.

Slavin S, Strober S, Fuks Z, Kaplan HS. 1977. Induction of specific tissue transplantation tolerance using fractionated total lymphoid irradiation in adult mice: Long-term survival of allogeneic bone marrow and skin grafts. J Exp Med 146: 34

Slavin S, Gottlieb M, Strober S, Bieber C, Hoppe R, Kaplan HS, Grumet FC. 1979. Transplantation of bone marrow in outbred dogs without graft-versus-host disease using total lymphoid irradiation. Transplantation 27: 139-142.

Smith CV, Suzuki T, Guzzetta PC, Nakajima K, Sundt TM, Mixon A, Spitzer TR, Eckhaus M, Sachs DH. 1993. Bone marrow transplantation in miniature swine: IV. Development of myeloablative regimens that allow engraftment across major histocompatibility barriers. Transplantation 56: $541-549$.

Spitzer TR. 2001. Engraftment syndrome following hematopoietic stem cell transplantation. Bone Marrow Transplant 27: 893-898.

Spitzer TR, Delmonico F, Tolkoff-Rubin N, McAfee S, Sackstein R, Saidman S, Colby C, Sykes M, Sachs DH, Cosim AB. 1999. Combined histocompatibility leukocyte antigen-matched donor bone marrow and renal transplantation for multiple myeloma with end stage renal disease: The induction of allograft tolerance through mixed lymphohematopoietic chimerism. Transplantation 68: 480484.

Spitzer TR, MCafee S, Dey BR, Colby C, Hope J, Grossberg H, Preffer F, Shaffer J, Alexander SI, Sachs DH, et al. 2003. Non-myeloablative haploidentical stem cell transplantation using anti-CD2 monoclonal antibody (MEDI507) - based conditioning for refractory hematologic malignancies. Transplantation 75: 1748-1751.

Spitzer TR, Sykes M, Tolkoff-Rubin N, Kawai T, McAfee SL, Dey BR, Ballen K, Delmonico F, Saidman S, Sachs DH, et al. 2011. Long-term follow-up of recipients of combined human leukocyte antigen-matched bone marrow and kidney transplantation for multiple myeloma with endstage renal disease. Transplantation 91: 672-676.

Strober S, Dhillon M, Schubert M, Holm B, Engleman E, Benike C, Hoppe R, Sibley R, Myburgh JA, Collins G, et al. 1989. Acquired immune tolerance to cadaveric renal allografts: A study of three patients treated with total lymphoid irradiation. $N$ Engl J Med 321: 28-33.

Strober S, Lowsky RJ, Shizuru JA, Scandling JD, Millan MT. 2004. Approaches to transplantation tolerance in humans. Transplantation 77: 932-936.

Strober S, Spitzer TR, Lowsky R, Sykes M. 2011. Translational studies in hematopoietic cell transplantation: Treatment of hematologic malignancies as a stepping stone to tolerance induction. Semin Immunol 23: 273-281.

Sundt TM III, Suzuki T, Kortz O, Eckhaus ME, Gress RE, Sachs DH. 1988. Induction of specific transplant tolerance in a large animal model by bone marrow transplantation. Surgical Forum 39: 365-367.

Sykes M, Sachs DH. 1988. Mixed allogeneic chimerism as an approach to transplantation tolerance. Immunol Today 9 : $23-27$. 
Sykes M, Sachs DH. 2001. Mixed chimerism. Philos Trans $R$ Soc Lond B Biol Sci 356: 707-726.

Sykes M, Sheard MA, Sachs DH. 1988. Graft-versus-hostrelated immunosuppression is induced in mixed chimeras by alloresponses against either host or donor lymphohematopoietic cells. J Exp Med 168: 2391-2396.

Takeuchi Y, Ito H, Kurtz J, Wekerle T, Ho L, Sykes M 2004. Earlier low-dose TBI or DST overcomes CD8 ${ }^{+}$ T-cell-mediated alloresistance to allogeneic marrow in recipients of anti-CD40 L. Am J Transplant 4: 31-40.

Tomita Y, Khan A, Sykes M. 1994. Role of intrathymic clonal deletion and peripheral anergy in transplantation tolerance induced by bone marrow transplantion in mice conditioned with a non-myeloablative regimen. J Immunol 153: 1087-1098.

Tomita Y, Khan A, Sykes M. 1996a. Mechanism by which additional monoclonal antibody injections overcome the requirement for thymic irradiation to achieve mixed chimerism in mice receiving bone marrow transplantation after conditioning with anti-T cell mAbs and 3 Gy whole body irradiation. Transplantation 61: 477-485.

Tomita Y, Sachs DH, Khan A, Sykes M. 1996b. Additional $\mathrm{mAb}$ injections can replace thymic irradiation to allow induction of mixed chimerism and tolerance in mice receiving bone marrow transplantation after conditioning with anti-T cell mAbs and 3 Gy whole body irradiation. Transplantation 61: 469-477.

Tonsho M. 2012. Induction of tolerance to heart allografts by donor kidney co-transplantation in nonhuman primates (NHPs). American Transplant Congress 2012 Conference Proceedings, Boston, p. 157.

Vallera DA, Taylor PA, Sprent J, Blazar BR. 1994. The role of host $\mathrm{T}$ cell subsets in bone marrow rejection directed to isolated major histocompatibility complex class I versus class II differences of $b m 1$ and $b m 12$ mutant mice. Transplantation 57: 249-256.

Valujskikh A, Fedoseyeva E, Benichou G, Heeger PS. 2002. Development of autoimmunity after skin graft rejection via an indirect alloresponse. Transplantation 73: 11301137.

Weiden PL, Sullivan KM, Flournoy N, Storb R, Thomas ED. 1981. Antileukemic effect of chronic graft-versus-host disease. New Engl J Med 304: 1529-1533.

Wekerle T, Sayegh MH, Hill J, Zhao Y, Chandraker A, Swenson KG, Zhao G, Sykes M. 1998. Extrathymic T cell deletion and allogeneic stem cell engraftment induced with costimulatory blockade is followed by central $\mathrm{T}$ cell tolerance. J Exp Med 187: 2037-2044.

Wekerle T, Kurtz J, Ito H, Ronquillo JV, Dong V, Zhao G, Shaffer J, Sayegh MH, Sykes M. 2000. Allogeneic bone marrow translantation with costimulatory blockade induces macrochimerism and tolerance without cytoreductive host treatment. Nat Med 6: 464-469.

Williams RC Jr. 1988. Hypothesis: Rheumatoid factors are antiidiotypes related to bacterial or viral Fc receptors. Arthritis Rheum 31: 1204-1207.

Wu Z, Bensinger SJ, Zhang J, Chen C, Yuan X, Huang X, Markmann JF, Kassaee A, Rosengard BR, Hancock WW, et al. 2004. Homeostatic proliferation is a barrier to transplantation tolerance. Nat Med 10: 87-92.

Yamada Y, Boskovic S, Aoyama A, Murakami T, Putheti P, Smith RN, Ochiai T, Nadazdin O, Koyama I, Boenisch O, et al. 2012. Overcoming memory T-cell responses for induction of delayed tolerance in nonhuman primates. Am J Transplant 12: 330-340.

Zinkernagel RM, Althage A, Callahan G, Welsh RM Jr. 1980. On the immunocompetence of $\mathrm{H}-2$ incompatible irradiation bone marrow chimeras. J Immunol 124: 23562365. 


\section{$\&_{\mathrm{CSH}}^{\infty} \&$ Cold Spring Harbor

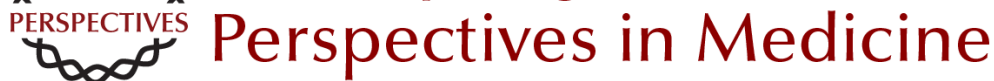

\section{Induction of Tolerance through Mixed Chimerism}

David H. Sachs, Tatsuo Kawai and Megan Sykes

Cold Spring Harb Perspect Med 2014; doi: 10.1101/cshperspect.a015529

Subject Collection Transplantation

Heart Transplantation: Challenges Facing the Field

Makoto Tonsho, Sebastian Michel, Zain Ahmed, et al.

Bioethics of Organ Transplantation Arthur Caplan

Overview of Clinical Lung Transplantation Jonathan C. Yeung and Shaf Keshavjee

Immunological Challenges and Therapies in

Xenotransplantation Marta Vadori and Emanuele Cozzi

Clinical Aspects: Focusing on Key Unique Organ-Specific Issues of Renal Transplantation Sindhu Chandran and Flavio Vincenti

T-Cell Costimulatory Blockade in Organ

Transplantation Jonathan S. Maltzman and Laurence A. Turka

Regulatory T-Cell Therapy in Transplantation: Moving to the Clinic

Qizhi Tang and Jeffrey A. Bluestone

Opportunistic Infections--Coming to the Limits of Immunosuppression?

Jay A. Fishman
Overview of the Indications and Contraindications for Liver Transplantation

Stefan Farkas, Christina Hackl and Hans Jürgen Schlitt

Facial and Hand Allotransplantation Bohdan Pomahac, Ryan M. Gobble and Stefan Schneeberger

Induction of Tolerance through Mixed Chimerism David H. Sachs, Tatsuo Kawai and Megan Sykes

Pancreas Transplantation: Solid Organ and Islet Shruti Mittal, Paul Johnson and Peter Friend

Tolerance--Is It Worth It? Erik B. Finger, Terry B. Strom and Arthur J. Matas

Lessons and Limits of Mouse Models Anita S. Chong, Maria-Luisa Alegre, Michelle L. Miller, et al.

Effector Mechanisms of Rejection Aurélie Moreau, Emilie Varey, Ignacio Anegon, et al.

The Innate Immune System and Transplantation Conrad A. Farrar, Jerzy W. Kupiec-Weglinski and Steven H. Sacks

For additional articles in this collection, see http://perspectivesinmedicine.cshlp.org/cgi/collection/ 